\title{
DEVELOPMENT OF ENGLISH LEARNING MODEL BASED ON LOCAL WISDOM WITH BLENDED LEARNING APPROACH USING MACROMEDIA FLASH AT SMPN SATU ATAP TUNDA ISLAND
}

\author{
1,2Dede Rohadi Fajri \& ${ }^{\mathbf{1}}$ Sisca Wulansari Saputri \\ ${ }^{1}$ Faculty of Teacher Training and Education, University of Banten Jaya, Indonesia \\ ${ }^{2}$ Corresponding Author Email: dederohadifajri@ unbaja.ac.id
}

\begin{tabular}{ll}
\hline \hline Article Info & Abstract \\
\hline $\begin{array}{l}\text { Article History } \\
\text { Received: September } 2021\end{array}$ & The aim of the research is to create a learning media model for English that uses \\
Revised: October 2021 & Macromedia Flash-based learning media to assist English. This study is a \\
Published: October 2021 & Research and Development $(R$ \& D) project with several stages. (1) Analysis \\
\hline Keywords & stages, such as identifying Learning Media objectives and student \\
English Learning; & characteristics; $(2)$ Design stages, such as designing learning materials and \\
Macromedia Flash; & learning media design using the Macromedia Flash program; (3) Production \\
Pulau Tunda; & stages, such as producing learning materials, authoring materials, and editing \\
& learning materials; (4) Stages of evaluation, including Material Expert Review, \\
& Media Expert Review, and Student Testing. The findings demonstrate that the \\
& English learning media products adhere to research and development guidelines \\
& and are successful in the learning process for SMPN Satu Atap Pulai Tunda \\
& students.
\end{tabular}

How to cite: Fajri, D. R., \& Saputri, S. W. (2021). Development of English Learning Model Based on Local Wisdom with Blended Learning Approach Using Macromedia Flash at SMPN Satu Atap Tunda Island, JOLLT Journal Languages and Language Teaching, 9(4), pp. 422-431. DOI: https://doi.org/10.33394/jollt.v\%vi\%i.4098

\section{INTRODUCTION}

Technological advancements have affected every aspect of human existence, including education (Kenedi et al., 2019). The implementation of technology in the educational system is extremely beneficial to the administration of education. One of the ways that technology is used in education is to implement the learning process in schools (Helsa et al., 2019). Because of the growth of the industrial revolution 4.0 period, which requires the use and development of technology in every area of life, including the learning process, the use of technology in the learning process is extremely essential to adapt. Because of the problems that must be met in the learning process, such as the education system's ability to create graduates with a variety of abilities based on mastery of technology, the period of the industrial revolution 4.0 necessitates the use of technology in the learning process (Helsa and Kendi, 2019). This is because graduates will confront increasingly complicated challenges in the future, which will necessitate mastery of technology in the problem-solving process. As a result, the use of technology in the learning process must be integrated.

The implementation of technology in the classroom has a positive influence on learning quality. 2011 (Hicks). Incorporating technology into the learning process can increase student learning results (Lee et al., 2011; Gadburry-Amyot et al., 2013, Naik et al., 2020). Furthermore, the usage of technology can help learners enhance their critical, creative, and higher-order thinking abilities (Pucer et al., 2014). As a consequence of the findings of this study, it can be stated that incorporating technology into the learning process can increase learning quality and that teachers must be able to apply it. It is the responsibility of teachers to be able to develop learning procedures that use technology. Teacher creativity is required in 
learning design in order to build an original, creative, dynamic learning environment that motivates students to learn via the use of technology.

Developing learning media is one of the ways technology may be used in the learning process. Studying media is a tool that teachers use to help pupils grasp what they're teaching (Helsa et al., 2019). The utilization of learning material is critical in the learning process. They are incorporating the learning process into the primary school curriculum. Students at elementary school are those who are in the midst of a certain operational time (Kiswanto, 2017, Pratiwi et al., 2020). Children learn via actual objects and direct student experience at this time. As a result, the instructor must be able to show real-world items and connect student experiences to the learning that will take place. The incapacity of all teachers to offer real things in the learning process is, nevertheless, a common stumbling block. As a result, using learning media as a manipulative tool to teach a topic to pupils is required. As a result, it is the teacher's responsibility to create learning media that is appropriate for the students' developmental stage.

Teaching methods and learning strategies have been developed around the world to improve students' English skills (Wang et al., 2011: 128)1. Applying interesting teaching and learning methods but still including the local wisdom of the surrounding community, which is very useful for supporting oral and written communication skills. The learning method used in this study is a game. The use of games in learning can make it easier for students to master the material with high enthusiasm.

Teachers did not employ instructional media throughout the learning process, according to observations conducted by researchers at SMPN Satu Atap Pulau Tunda in Tirtayasa District, Serang Regency. The subject is solely explained in a traditional manner by the teacher. As a result, learners simply paid attention to the teacher's delivery of content. Students are likely uninterested in the subject provided by the teacher, and others appear bored when the material is presented. When the teacher assigns the task, the pupils appear to be uninterested in doing it. Students express dissatisfaction with the homework they have been assigned. Even learners strive to imitate their friend's work. According to the researcher's interpretation of the observations, the issue was that the instructor did not employ learning material that was appropriate for the students' growth, resulting in poor student motivation. The findings of this study are bolstered by the outcomes of distributing learning motivation questionnaires to students. In the low category, these results show an average score of 54 students.

Based on the description above, researchers feel the need to provide an update on teaching materials based on Macromedia Flash by adopting materials about Local Wisdom. The researchers' update was the learning process that was previously carried out face-to-face in the classroom. Now with the application of learning media with Macromedia Flash, the learning process can be carried out remotely.

\section{Development of Local Wisdom Based Learning Model}

Learning is an effort so that students can be independent with their abilities. Conscious learning is carried out to translate actual and perfect things to achieve superior and perfect humans who are suitable for learning and life goals (Mudyaharjo, 2012; Muhmidayeli, 2011). Therefore, the quality of learning must continue to be improved with the challenges and needs in preparing quality and competitive human energy sources. The increase in the quality of learning must also be in line with efforts to protect Indonesian culture, which is starting to be replaced by foreign culture by westernization. (Suharni, 2019) said that westernization is an excessive imitation of Western-style by adopting their lifestyle in totality without any filter filtering it, imitating all aspects of life both in terms of fashion, behavior, culture, and others. The imitative behavior interferes with national culture and language. Cooperation between countries and the massive influence of globalization provide benefits and negative 
consequences that criticize Indonesian culture. Indonesian culture is starting to be displaced by foreign cultures such as television activities, exposing young people to foreign styles and cultures, and reducing their attention to Indonesian regional arts (Surahman, 2017). In view of this, students must be encouraged from an early age to get closer and understand the local culture. Each region in Indonesia has values that need to be internalized. Therefore, it means to include local wisdom as the main content of teaching materials in elementary schools.

Teaching materials based on local wisdom act as a facility for internalizing cultural values and are more comfortable to understand because they are more contextual, close to student learning areas, and can improve learning outcomes (Anggramayeni, Yolida, \& Marpaung, 2018; Zinnurain \& Muzanni, 2018). Teaching materials based on local wisdom will be more useful if they have local cultural values and can also improve the survival skills needed in this 21 st century.

Teaching materials have a significant position in achieving the educational goals that have been planned. Teaching materials are data, equipment, and readings needed by teachers/instructors to design and pursue educational applications systematically arranged based on the competencies students want to understand in the educational process (Prastowo, 2014; Sofan \& Ahmadi, 2010). Teaching materials used in education are not only practicing novels from the government, but teachers can also improve teaching materials based on local wisdom. Local wisdom is often referred to as local wisdom, local wisdom, people knowledge, local knowledge, folk knowledge, indigenous knowledge, or traditional wisdom. For Kun (2013), local wisdom can be referred to as local ideas that have wisdom, prudence, good values, which are believed and adhered to by members of the community. Local wisdom is a way of thinking about life and knowledge and various life strategies in the form of activities that are tried by local residents in responding to various cases related to their needs. (Maryani \& Yani, 2015) said that as a result of local wisdom, everything that lives and is believed to be true from one generation to the next becomes a guide for residents on how to behave.

\section{Macromedia Flash}

Macromedia Flash 8 is software designed to create vector-based animations, and the resulting size is smaller. Initially, this software was designed to create animations or internetbased applications (online). But in its development, it is widely used to create animations or non-internet (offline) applications. With the 2.0 Action script included with Flash, Flash can be used to develop games or teaching materials, such as quizzes or simulations.

\section{Understanding Online Games}

Online games are games that are used by someone for personal enjoyment and online games can also be used as educational tools. Goals, rules, challenges, and interactions that occur are the most important parts of online games. Therefore, online games have positive and negative impacts on learning, especially in learning a new language. Every learning must have both of these impacts. There is no learning that only has a positive impact. The impact of playing online games is that we can have a sense of anxiety and a sense of being motivated for new things. Anxiety is a negative impact because when someone is learning from online games, they will indirectly learn vocabulary that is not in the context in the game itself. While the positive impact that we can get from online games is that someone will be able to improve concentration, language skills, and the ability to interact with others (Reinders \& Wattana; $2014)^{12}$.

\section{RESEARCH METHOD}

The model through which the study is conducted is referred to as the research method (Borg \& Gall, 1983). Because of its applicability, the model employed in this study was used by some of the participants. The preliminary study stage of the research entails document 
analysis, classroom observation, and interviewing; the development stage entails writing, internal expert judgment, and revision; and the field testing stage entails try out, external expert judgment, and revision.

\section{Needs Analysis}

At this stage, the Research Chair conducts a needs analysis in the form of gathering information about learning materials that will be delivered with Macromedia Flash. The problems analyzed are analyses of problems contained in the learning process in the field to identify possible solutions that can be applied to overcome these problems. Content analysis to find out the learning components in the form of Competency Standards, Basic Competencies, Learning Objectives, and Material Content in accordance with the syllabus.

Design: The design stage was carried out by Research Member 1 to find appropriate and interactive learning media based on material that had been determined in the previous stage. At this stage, a screen display design sketch is needed to make it easier for programmers to translate into a more real form. The design is made in a storyboard to facilitate the implementation of the design. Design Implementation: The implementation session is the process of translating the design into the actual view which is carried out by the Chair and Research Members. The development used is PC-based multimedia. The program used to translate this design is in the form of a Macromedia Flash program to create animations in the form of photos or readings.

Then, Testing: This session is where this educational media is checked. This session is more about checking the navigation buttons whether there are errors in giving commands, inaccessible navigation, checking interfaces, module errors, or arrangement errors. This session is reviewed one by one by the author manually and will be reviewed by media experts and module experts in the educational media validation session. Then, Expert Validation: This stage is the stage of testing or checking whether the learning media has navigation buttons, whether there are errors in issuing orders, navigation errors, and errors in the material. The next stage is the expert verification stage or expert judgment. In this study, the verification stage is the initial test. This is done to find out whether the media created is suitable for interactive learning media. If the verified media is in accordance with its category and does not need to be modified, interactive learning media can be implemented in the field. At the same time, the materials expert will evaluate the completeness and applicability of the materials and media based on the syllabus, and the media expert will evaluate the media design. Revision: After expert verification, the interactive learning media will be modified based on expert input. If the verified media is in accordance with its category and does not need to be modified, interactive learning media can be implemented in the field.

Feasibility Test: After the expert stated that the interactive learning media was feasible, a field trial was carried out on the media (in this SMP learning). The school that became the resource person for the media trial was grade 2 students. Students tried to produce media and provide their responses. Media Improvement: After the test is carried out in schools with students as respondents, input from students will be increased. If improvements cannot be made, input will be given for further research. Last, Products: The products produced are in the form of English animal name recognition educational games, suitable as learning media in the learning process at school.

This research has been carried out a needs analysis (initial) in January 2021 and the design will be carried out in February-March 2021; before this research is carried out, in April - Media experts and material experts will carry out may testing, and in May it will be carried out testing by respondents. The object to be studied in this research is the second-grade students of junior high school on the coast of Pulau Tunda. 


\section{RESEARCH FINDINGS AND DISCUSSION Research Findings}

Stage of Product Development

The development of learning media using the Macromedia Flash program has the procedure steps that have been carried out, namely:

Design Stages

Before defining the first product design idea of learning media using Macromedia Flash, the design stage must be completed. The following are some of the first actions that have been completed: Design learning materials: Determine Competency Standards in accordance with the curriculum, making Semester Syllabus and Learning Plans, determine the material to be used, determine reference books that are in accordance with the material, make an evaluation, designing learning media designs using Macromedia flash collect material (materials in the form of graphics, images, sound, pictures, animations, videos, and presentations.

Production Stage.

The study's findings have resulted in the creation of interactive learning tools for English classes. This lesson material is in the form of flash (swf) and HTML, and it can be viewed using Adobe Flash Player.

The display of English learning media programs using Flash is as follows:

\section{Intro Display}

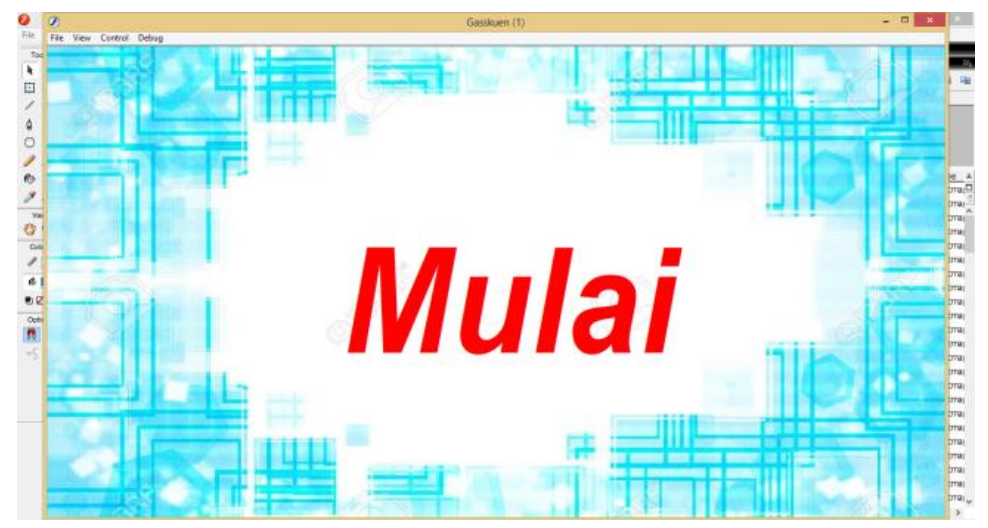

The picture shows the direction to press Mulai to start the media.

Home Menu Display

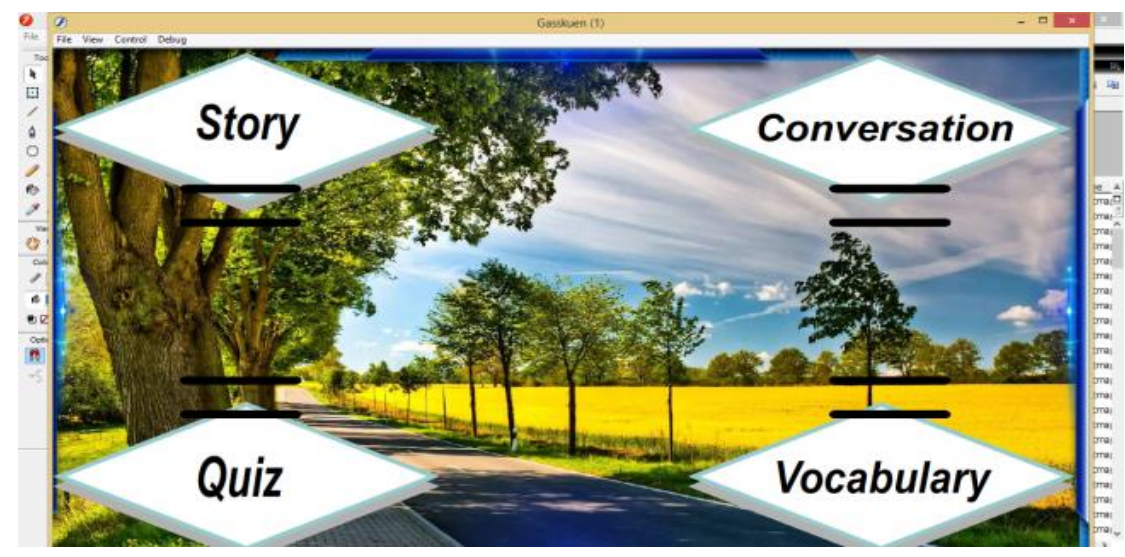


The image depicts the display of the home menu, which contains various options, including Conversation, Story, Quiz, and Vocabulary.

\section{Display of Conversation}

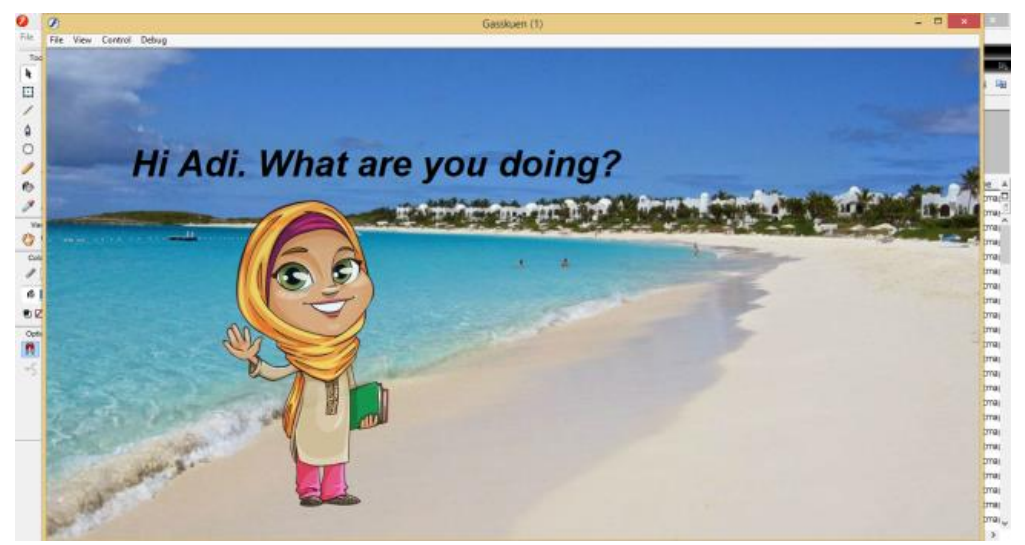

The picture shows the animation of conversation.

Display of Story

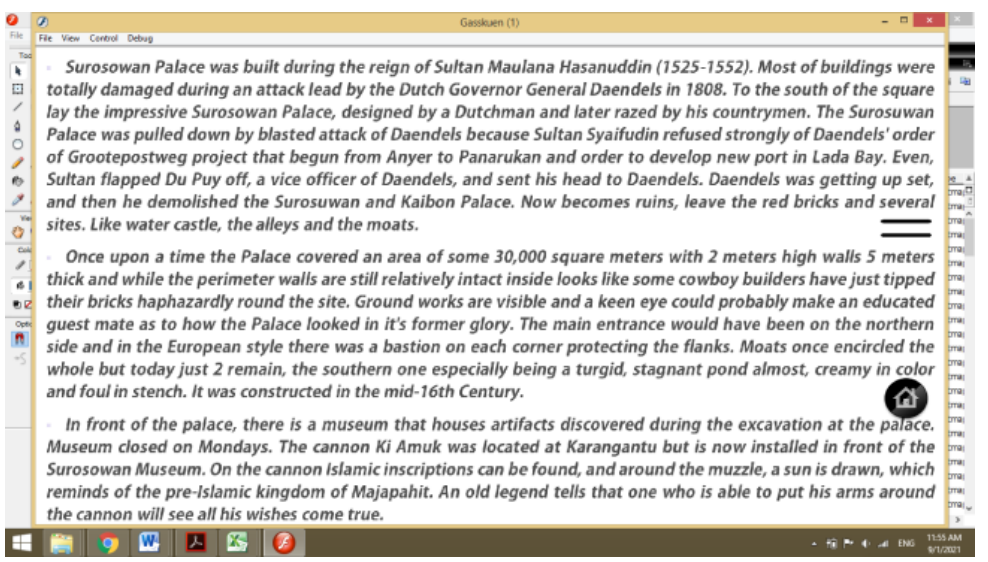

Display of Quiz

1. Which one is more difficult 2 . What do you think about
3. Which one does you like best__ ?
4. Are you interest in
5. What s sour opinion on
6. Which one is more important
7. Do you think that or
8. Do you have an opinion on is boring?




\section{Display of Vocabulary}

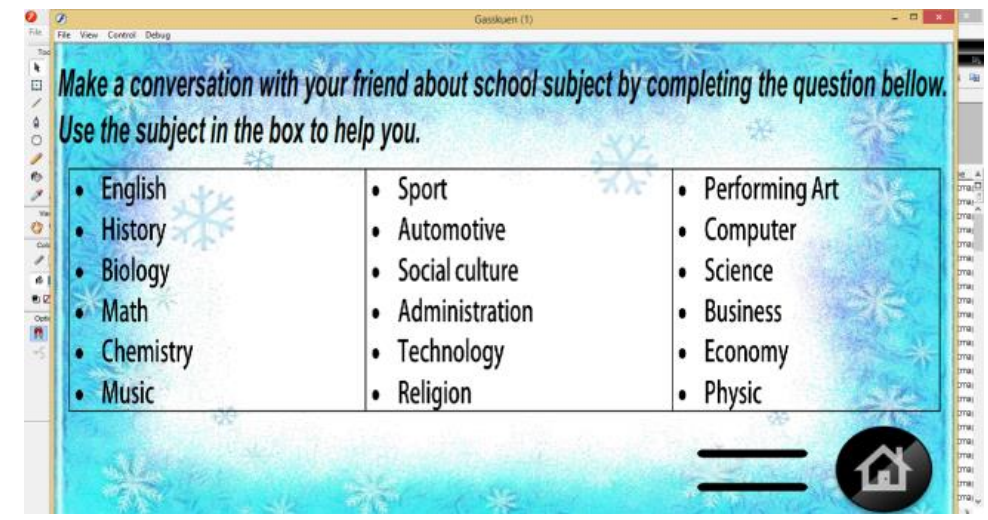

\section{Evaluation Stage}

\section{Data Analysis of Materials' Validation Result}

Validation of material experts was carried out by Dr. Yayu Heryatun, M.Pd, Senior Lecturer at the UIN SMH Banten English Language Department. She is a Doctor of applied Linguistics. She also taught Methodology of TEFL. Based on the results of the material aspects validation, it can be seen the quality of the instructional media material developed. This validation aims to determine the suitability of the material needed by students. Material aspects are related to material suitability with Competency Standards, Accuracy of material coverage, Material truth, Up to date material, Digestibility of materials, Submission of coherent material, Useful material, Depth of material, Weighted material, Interesting material, Ease of material delivery, Evaluation for measuring student ability, student involvement in learning activities, accurate learning resources, and quality feedback (can motivate students). In the notes of suggestions and comments, the material expert suggested to the researcher to immediately apply this media to the students. In addition, material experts gave criticism to add competency standards to one of the slightest. The score obtained is 4.60. Based on the conversion, qualitative values are included in the excellent category.

\section{Data Analysis Results of Media Aspect Validation}

Rizki Fatullah, S.Kom., MTI, conducts the validation of media specialists. He is a computer specialist and lecturer at the University of Banten Jaya's Design \& Multimedia Courses. He's also a specialist in the subject of learning media, with a specialization in Macromedia Flash applications. The display quality and learning media programs produced may be seen based on the results of the media aspect validation. Aspects of the media include font selection, font size, color, graphics, background selection accuracy, image display, animation, music accompaniment, sound, screen design, language usage, navigation, button consistency, clarity of usage instructions, ease of use, efficiency layer usage, text efficiency, speed, anticipating possible student responses. Based on advice from media experts, several writings must be corrected, improved videos, and quizzes. When viewed from the scores obtained, the learning media in the good category is 4.05 .

\section{Test Results on Student}

It is used as a basis for knowing the breadth and appropriateness of the content with the demands of students based on the results of the trials on students. These factors include the readability of the program's instructions, the quality of the image display, the presentation of animation, the background composition, the selection of background, music support, 
navigation, the clarity of competency standards and basic competencies to be mastered, the clarity of learning instructions, and the ease of understanding, the substance of the lesson, correctness of presenting sequence, breadth of practice/quiz delivery, the function of learning media in providing insight and understanding, clarity of feedback/response, and increased interest in learning.

The information gathered from student trials was then translated to a 5-point scale. Based on the data analyzed, with 17 items verified by 33 students, the number of students who picked the category was very good was 79 , the categories were 272 , enough categories were 167, there were 12 categories that chose poor, and there were ten categories that chose very poor. After being tested on students, the learning material is placed in the good category with an average score of 3.60 .

\section{Discussion}

Because middle school learners are in the concrete operational stage, learning in middle schools must employ learning media. Children must learn from actual items at this stage, and teachers must be able to offer real objects or manipulative objects so that students can comprehend the learning content (Mansur et al., 2017). Junior school kids need to be motivated to learn. The quality of learning will be influenced by learning motivation (Hamdu and Agustina, 2011). As a result, teachers must be able to enhance learners' drive to study. Based on these findings, a learning medium that can boost student learning motivation in accordance with the features of primary school children, as well as the characteristics of the fourth industrial revolution age, is required. As a result, in order to improve the learning motivation of junior high school learners, interactive multimedia employing Macromedia flash 8 software must be created.

The next stage is to examine the curriculum after determining the main reason for producing multimedia. The goal of curriculum analysis is to figure out what kind of multimedia content needs to be created. The design stage is the next step. There are two actions at this stage: creating flowcharts and creating narrative boards. The goal of flowcharts is to demonstrate the flow and interrelationships of the programs that have been created. The storyboard is created when the flowchart is completed. The purpose of the narrative board is to offer details about the multimedia creation process. Following the creation of flowcharts and storyboards, Macromedia flash 8 is used to create interactive multimedia. After the multimedia has been created, expert validation is performed. The goal of expert validation is to assess whether the created multimedia is feasible. Media expert validation, material expert validation, and linguist validation are the three specialists involved in expert validation.

This learning material has been approved by material and media specialists, and it has progressed through the phases of development in the same way. The material expert validation yielded a score of 4.60, the media expert validation generated a score of 4.05 , and the results of student exams were included in the good criterion with a score of 3.60. This learning material contains strengths and limitations as a result of product development. The following are some of the advantages: (1) a different perspective on the learning media previously utilized. This learning media is an interactive learning media that students may access at any time and from any location, (2) The primary appeal of learning media utilizing this Macromedia Flash 8 program is the presentation of the content provided by presenting numerous animations, as well as the availability of quizzes and summaries. (3) Having interactive and consistent navigation buttons to allow students to quickly explore each slide (4) The program's qualities include minimal file size, making it highly profitable if it's uploaded to the internet, (5) Because it has been published in the.Exe format, this program has an auto-run file and is instantly executed/running. As a result, the Macromedia Flash 8 
application does not need to be installed before it can be utilized; (6) It may be used for selfstudy.

This research claims that interactive multimedia created with macromedia flash 8 software helped junior high school pupils become more motivated to learn. This result demonstrates that incorporating aspects of technology into learning material can increase the quality of learning. This study may be utilized as a resource for educators, particularly those working in secondary schools, who want to improve student learning motivation by developing technology-based learning media. However, because it focused solely on one subtheme of class VII, this study had limitations. To make the research findings more reliable, further research is required.

\section{CONCLUSION}

Based on the results of data analysis and discussion can be concluded as follows: The creation of learning media with Macromedia Flash has gone through several stages, including: (1) the analysis phase, which includes the identification of learning media objectives and student characteristics; (2) the development phase, which includes the creation of learning media with Macromedia Flash; and (3) the implementation phase, which includes the creation of learning media with Macromedia Flash. (2) The design stage entails creating storyboards, deciding layouts, drawing block diagrams, and gathering resources in the form of graphics, pictures, sound, picture, animation, and choosing the application software to be utilized, among other things. (3) the production step, which involves putting together layouts, designs, and resources that have previously been created to produce a learning media product, (4) The evaluation stage, during which it was reviewed and evaluated by a group of material and media specialists. Compact Disk contains the results of the Macromedia Flash 8 program's development.

The quality of learning media products in the English course at SMPN Satu Atap Pulau Tunda was assessed based on material experts' and media experts' assessments, as well as the results of a survey. Student trials, which included features of material feasibility based on material specialists' assessments, scored very well, with a mean score of 4.60 . The factor of media feasibility has a mean score of 4.05. It is based on the opinion of media professionals in a good category. The trial outcomes for students are adequately classified, with a mean score of 3.60. So that students and lecturers may utilize it as a learning medium in the classroom.

\section{REFERENCES}

Abadi Prastowo, A. (2014). Panduan Kreatif Membuat Bahan Ajar Inovatif.

Anggramayeni, A., Yolida, B., \& Marpaung, R. R. T. (2018). Efektivitas Bahan Ajar Berbasis Kearifan Lokal terhadap Aktivitas dan Hasil Belajar Peserta Didik. Jurnal Bioterdidik: Wahana Ekspresi Ilmiah, 6(5).

Gadbury-Amyot, C. C., Singh, A. H., \& Overman, P. R. (2013). Teaching with technology: learning outcomes for a combined dental and dental hygiene online hybrid oral histology course. Journal of dental education, 77(6), 732-743.

Gall, M. D., Borg, W. R., \& Gall, J. P. (1996). Educational research: An introduction. Longman Publishing.

Helsa, Y., \& Kenedi, A. K. (2019). Edmodo-Based Blended Learning Media in Learning Mathematics. Journal Of Teaching And Learning In Elementary Education (JTLEE), 2(2), 107-117.

Kenedi, A. K., Ahmad, S., Sofiyan, T. A. N., \& Helsa, Y. (2019). The Mathematical Connection Ability of Elementary School Students in the 4.0 Industrial Revolution Era. International Journal of Innovation, Creativity and Change, 5(5), 458-472. 
Kiswanto, A. (2017, September). The effect of learning methods and the ability of students think logically to the learning outcomes on natural sciences of grade ivs student. In 9th International Conference for Science Educators and Teachers (ICSET 2017) (pp. 10401046). Atlantis Press.

Kun, P. Z. (2013, September). Pembelajaran sains berbasis kearifan lokal. In Seminar Nasional Fisika dan Pendidikan Fisika Ke-3 2013. Sebelas Maret University.

Lee, S. J., Srinivasan, S., Trail, T., Lewis, D., \& Lopez, S. (2011). Examining the relationship among student perception of support, course satisfaction, and learning outcomes in online learning. The Internet and Higher Education, 14(3), 158-163.

Maryani, E., \& Yani, A. (2015). Local Wisdom of Kampung Naga in Mitigating Disaster and Its Potencies for Education Tourism Destination. ASEAN Journal on Hospitality and Tourism, 14(2), 72-85.

Mudyaharjo, R. (2012). Filsafat Ilmu Pendidikan: Suatu Pengantar. Bandung: PT. Remaja Rosdakarya

Muhmidayeli, M. (2011). Filsafat Pendidikan. Bandung: PT. Refika Aditama.

Naik, G., Chitre, C., Bhalla, M., \& Rajan, J. (2020). Impact of use of technology on student learning outcomes: Evidence from a large-scale experiment in India. World Development, 127, 104736.

Reinders, H., \& Wattana, S. (2014). Affect and willingness to communicate in digital gamebased learning.

Sugiyono. (2010). Metode Penelitian Pendidikan, Pendekatan Kuantitatif, Kualitatif, dan R\&D. Bandung: Alfabeta.

Suharni, S. (2019). Westernisasi Sebagai Problema Pendidikan Era Modern. Jurnal ALIJTIMAIYYAH: Media Kajian Pengembangan Masyarakat Islam, 1(1). Retrieved From https://jurnal.ar-raniry.ac.id/index.php/PMI/article/view/255

Surahman, S. (2017). Dampak Globalisasi Media Terhadap Seni dan Budaya Indonesia. Lontar: Jurnal Ilmu Komunikasi, 2(1). https://doi.org/10.30656/lontar.v2i1.334

Sofan, A., \& Ahmadi, L. K. (2010). Konstruksi Pengembangan Pembelajaran Pengaruhnya terhadap Mekanisme dan praktik kurikulum. Jakarta: Prestasi Pustaka.

Umam, K., \& Yudi, Y. (2016). Pengaruh Menggunakan Software Macromedia Flash 8 Terhadap Hasil Belajar Matematika Siswa Kelas VIII. Kalamatika: Jurnal Pendidikan Matematika, 1(1), 84-92.

Pratiwi, S. I., Kristen, U., Wacana, S., Salatiga, K., \& Tengah, J. (2020). Pengaruh ekstrakurikuler pramuka terhadap karakter disiplin siswa sd. Edukatif: Jurnal Ilmu Pendidikan, 2(1), 62-70.

Pucer, P., Trobec, I., \& Žvanut, B. (2014). An information communication technology based approach for the acquisition of critical thinking skills. Nurse education today, 34(6), 964-970.

Wahyugi, R., \& Fatmariza, F. (2021). Pengembangan Multimedia Interaktif Menggunakan Software Macromedia Flash 8 Sebagai Upaya Meningkatkan Motivasi Belajar Siswa Sekolah Dasar. Edukatif: Jurnal Ilmu Pendidikan, 3(3), 785-793.

Wang, Y. J., Shang, H. F., \& Briody, P. (2011). Investigating the impact of using games in teaching children English. International journal of learning and development, 1(1), 127141

Zinnurain, Z., \& Muzanni, A. (2018). Pengembangan Buku Ajar Berbasis Kearifan Lokal Pada Siswa Kelas V Sekolah Dasar. Jurnal Ilmiah IKIP Mataram, 4(2), 63-69. 